\title{
PELATIHAN PENGGUNAAN APLIKASI ZOOM UNTUK PROSES PEMBELAJARAN DARING PADA MASA PANDEMI COVID-19 DI SD NEGERI 10 CAKRANEGARA
}

\author{
(Training on Using Zoom Application for Online Learning Process During The \\ Covid-19 Pandemic at SD Negeri 10 Cakranegara)
}

\author{
Ramaditia Dwiyansaputra $^{[1]}$, I Gede Pasek Suta Wijaya ${ }^{[1]}$, Fitri Bimantoro ${ }^{[1]}$, \\ Gibran Satya Nugraha ${ }^{[1]}$, Arik Aranta ${ }^{[1]}$ \\ ${ }^{[1]}$ Program Studi Teknik Informatika, Universitas Mataram \\ Jl. Majapahit 62, Mataram, Lombok NTB, INDONESIA \\ Email:rama@unram.ac.id, [gpsutawijaya,bimo, gibransn, arikaranta]@unram.ac.id
}

\begin{abstract}
Abstrak
Pandemi Covid-19 memiliki dampak yang besar dan mendorong banyak perubahan dalam berbagai sektor kehidupan masyarakat, termasuk juga dalam hal pendidikan. Di Indonesia, sekolah-sekolah diharuskan untuk mengubah proses pembelajaran yang lazimnya dilakukan dengan cara tatap muka secara langsung dalam sebuah kelas, menjadi pembelajaran secara daring atau pembelajaran jarak jauh untuk mencegah penularan Covid-19. Namun, proses pembelajaran daring ini mengalami kendala karena masih kurangnya pemahaman dan keterampilan guru atau tenaga pengajar dalam memilih dan mengelola media pembelajaran daring yang berbasiskan teknologi. Untuk membantu mengatasi kendala ini, maka perlu untuk dilakukan kegiatan pelatihan untuk para guru agar dapat menggunakan salah satu aplikasi yang cukup mudah dan dapat membantu proses pembelajaran daring yakni aplikasi Zoom Meeting. Kegiatan pelatihan ini dilaksanakan di salah satu SD Negeri di Kota Mataram, yaitu SD Negeri 10 Cakranegara. Metode pelatihan yang digunakan adalah ceramah, tutorial, diskusi dan juga praktik. Hasil yang diperoleh dari pelatihan ini adalah para guru mendapatkan pemahaman dan memiliki keterampilan untuk mengelola dan melaksanakan metode pembelajaran daring menggunakan aplikasi Zoom sehingga proses pembelajaran jarakjauh pada era pandemi ini dapat berjalan lebih efektif dan efisien.
\end{abstract}

Keywords: Aplikasi Zoom; Pembelajaran Daring; Pembelajaran Jarak Jauh; PJJ; Covid-19.

\section{Pendahuluan}

Covid-19 (Coronavirus Disease 2019) merupakan jenis virus baru yang dilaporkan pertama kali muncul di Wuhan Tiongkok pada bulan Desember tahun 2019 [1]. Virus ini dapat menginfeksi manusia dan menular dengan begitu cepat serta mengakibatkan kematian yang cukup tinggi. Wabah virus ini kemudian ditetapkan sebagai pandemi oleh World Heath Organization (WHO) karena jumlah penyebaran virus yang bertambah secara signifikan dan berkelanjutan secara global [2]. Beberapa kebijakan pun dibuat untuk menghentikan penyebaran virus ini, seperti wajib penggunaan masker, menerapkan physical distancing atau menjaga jarak untuk menghindari kontak fisik, dan bahkan melakukan lockdown (pembatasan sosial) di daerah-daerah yang penularannya sudah cukup parah.

Pandemi Covid-19 ini sangat berdampak besar terhadap perubahan tatanan kehidupan di dunia. Salah satu sektor yang paling nyata terdampak selain sektor kesehatan dan ekonomi adalah sektor pendidikan. Pada sektor pendidikan, untuk mencegah penularan Covid-19, banyak negara, termasuk juga pemerintah Indonesia, mengeluarkan kebijakan agar seluruh aktivitas pembelajaran di sekolah dihentikan dan dialihkan dengan kebijakan belajar dari rumah dengan sistem pembelajaran jarak jauh (PJJ) sejak 24 Maret 2020 [3]. Perubahan proses pembelajaran yang lazimnya dilakukan dengan cara tatap muka secara langsung dalam sebuah kelas menjadi pembelajaran daring ini menjumpai banyak kendala yang sangat merugikan bagi kemajuan pendidikan di Indonesia karena pendidikan merupakan suatu hal yang sangat penting untuk generasi penerus bangsa.

Salah satu kendala yang dihadapi dengan perubahan proses pembelajaran tersebut adalah biaya proses pembelajaran yang semakin bertambah karena dibutuhkan biaya untuk teknologi yang digunakan dalam proses pembelajaran daring. Salah satu contoh yang memerlukan biaya tambahan adalah penyediaan pulsa untuk kuota internet. Kuota internet ini sangat dibutuhkan dalam proses penyediaan dan pengaksesan materi pembelajaran secara daring. Untuk mengatasi kendala biaya tambahan ini, pemerintah Indonesia melalui Kementerian Pendidikan dan Kebudayaan telah mengeluarkan kebijakan yakni relaksasi dana Bantuan Operasional Sekolah (BOS) yang dapat 
digunakan oleh satuan pendidikan untuk penyediaan pulsa kuota internet bagi guru dan siswa. Selain itu, pemerintah juga akan memberikan subsidi kuota internet bagi siswa dan juga guru terhitung dari bulan September sampai Desember 2020.

Kendala lainnya yang muncul yakni keterbatasan penguasaan keterampilan teknologi informasi baik oleh para guru maupun siswa. Kondisi guru di Indonesia tidak seluruhnya paham penggunaan teknologi informasi dan hal ini membatasi mereka dalam memilih dan menggunakan media daring yang dapat lebih efektif dan efisien untuk menunjang proses pembelajaran jarak jauh. Akibat dari hal ini, banyak para guru yang hanya memberikan materi dan tugas kepada para siswanya untuk dipelajari dan dikerjakan secara mandiri di rumah masing-masing. Proses pembelajaran daring tidak hanya sekedar membagikan materi pembelajaran, namun harus ada proses kegiatan belajar mengajar secara daring. Selain interaksi dengan materi pembelajaran, dibutuhkan juga adanya interaksi antara pembelajar dengan pengajar serta interaksi antara sesama pembelajar (antar siswa) lainnya [4].

Salah satu contoh sekolah yang masih kesulitan untuk memilih metode pembelajaran daring yang tepat adalah SD Negeri 10 Cakranegera. SDN 10 Cakranegara adalah salah satu sekolah dasar negeri di kota Mataram, Nusa Tenggara Barat. SD yang telah berdiri sejak tahun 1955 ini, sejak awal pandemi memanfaatkan aplikasi Whatsapp untuk berinteraksi dengan peserta didik. Para guru kelas masing-masing membuat grup pada aplikasi Whatsapp dan memasukkan para peserta didiknya ke dalam grup tersebut. Para guru juga kemudian dapat menyampaikan materi pembelajaran ataupun tugas melalui grup Whatsapp tersebut. Cara ini dirasa masih kurang efektif oleh Kepala Sekolah dan para guru sehingga berusaha untuk mencari alternatif teknologi pembelajaran daring lainnya.

Untuk membantu SD Negeri 10 Cakranegara, maka dipandang perlu untuk melaksanakan kegiatan pelatihan penggunaan aplikasi yang dapat digunakan dalam proses pembelajaran jarak jauh. Salah satu teknologi pembelajaran daring guna menunjang pembelajaran jarak jauh adalah penggunaan aplikasi kelas virtual seperti contohnya adalah aplikasi Zoom. Aplikasi Zoom merupakan platform untuk melakukan konferensi video berbasiskan komputasi awan (cloud computing) [5]. Aplikasi ini memberikan kemudahan untuk guru dan siswa agar dapat bertatap muka dan berinteraksi selayaknya bertemu langsung dalam ruang daring. Platform ini memiliki cukup banyak fitur, mudah untuk digunakan dan bersifat gratis (dengan beberapa batasan) sehingga dapat digunakan oleh siapa pun dan cocok untuk digunakan sebagai media pembelajaran daring. Proses pembelajaran menggunakan aplikasi Zoom ini juga dapat direkam dan kemudian hasil rekaman tersebut dapat diunggah ke platform Youtube sehingga dapat dilihat kembali oleh peserta didik.

\section{Tinjauan Pustaka}

\subsection{Pembelajaran Jarak Jauh di Era Pandemi}

Pembelajaran jarak jauh (PJJ) merupakan proses belajar mengajar yang dilakukan secara jarak jauh melalui penggunaan berbagai media komunikasi (teknologi dan komunikasi) [6]. Tujuan dilakukannya PJJ ini adalah untuk memberikan layanan pendidikan kepada kelompok masyarakat yang tidak dapat mengikuti pendidikan secara tatap muka dan juga memperluas akses serta mempermudah layanan pendidikan dalam pendidikan dan pembelajaran. PJJ diselenggarakan dalam berbagai bentuk, modus dan cakupan yang didukung oleh sarana dan layanan belajar serta sistem penilaian yang menjamin mutu lulusan.

PJJ merupakan pilihan utama selama masa penyebaran Covid-19 di berbagai negara, termasuk juga Indonesia. Sejak tanggal 24 Maret, pemerintah Indonesia melalui Kementerian Pendidikan dan Kebudayaan mengeluarkan Surat Edaran yang menginstruksikan sekolah untuk melakukan proses pembelajaran dari rumah [3]. Berdasar Surat Edaran tersebut, dalam melaksanakan PJJ para guru dituntut untuk kreatif dan inovatif guna memacu semangat siswa dalam belajar.

Model PJJ yang merupakan salat satu cara yang paling efektif untuk mencegah penularan Covid-19, namun model pembelajaran ini menimbulkan berbagai reaksi dan permasalahan bagi masyarakat. Pertama, PJJ yang mengharuskan pihak sekolah untuk dapat kreatif dan inovatif cukup menyulitkan sekolah karena harus memanfaatkan teknologi informasi untuk mewujudkan model PJJ yang efektif dan efisien. Keterampilan tenaga pendidik untuk mengadopsi teknologi tersebut tidak merata. Kedua, PJJ memberikan tugas ekstra bagi orang tua peserta didik untuk memantau dan mempersiapkan perangkat pembelajaran jarak jauh, seperti gadget, laptop dan jaringan internet atau kuota pulsa internet.

\subsection{Aplikasi Zoom untuk PJJ}

Zoom merupakan sebuah layanan konferensi video berbasiskan komputasi awan [5]. Aplikasi ini memudahkan pengguna untuk bertatap muka secara virtual menggunakan video, suara ataupun keduanya. Aplikasi Zoom bersifat 
gratis sehingga dapat digunakan oleh siapa pun dengan batas waktu 40 menit untuk jumlah peserta lebih dari 2 orang dan tidak ada batasan waktu jika memiliki akun yang berbayar. Pembayaran ini hanya dilakukan hanya oleh host (yang membuat meeting/pertemuan daring) saja, sedangkan untuk menggunakan aplikasi Zoom hanya sebagai peserta saja, tidak diperlukan untuk melakukan pembayaran [7]. Beberapa fitur utama aplikasi Zoom di antaranya sebagai berikut:

1. Pertemuan one-on-one. Host dapat melakukan pertemuan hanya berdua atau pertemuan 1:1 (one-on-one) tanpa batas waktu penggunaan untuk akun gratis.

2. Pertemuan kelompok (grup). Untuk akun gratis, Host dapat mengundang peserta maksimum sebanyak 100 peserta dengan batas waktu 40 menit.

3. Sharing screen (berbagi layar). Peserta dengan pertemuan one-on-one atau kelompok besar dapat berbagi layar dengan peserta lain, sehingga peserta lain dapat melihat apa yang terlihat di layar monitor peserta yang melakukan share screen.

4. Fitur chat. Peserta dapat berkirim pesan antar peserta meeting (pertemuan daring) baik ke semua peserta sekaligus ataupun secara pribadi ke salah satu peserta.

5. Fitur recording (merekam). Host dapat merekam pertemuan daring ke cloud atau ke penyimpanan lokal komputer pengguna.

Pengabdian kepada masyarakat terkait penggunaan aplikasi Zoom untuk pembelajaran jarak jauh juga telah banyak dilakukan, di antaranya adalah pengabdian pada guru di SDN 17 Mata Air Padang Selatan [8], pelatihan Zoom Cloud Meeting untuk guru SMK Muhammadiyah Kab. Sorong [9] dan pelatihan terhadap guru tingkat Sekolah Dasar dan Sekolah Menengah Pertama se-Kabupaten Bangka [10]. Aplikasi Zoom cukup banyak digunakan untuk membantu proses pembelajaran jarak jauh dikarenakan karena kualitas yang baik dan kemudahan penggunaannya. Salah satu kelebihan aplikasi Zoom yang bermanfaat apabila digunakan sebagai media pembelajaran adalah bahwa siswa yang akan menggunakan aplikasi Zoom tidak perlu untuk membuat akun, sehingga proses untuk bergabung ke pertemuan daring yang dibuat oleh guru menggunakan aplikasi Zoom sangat mudah.

\section{Metode Pengabdian masyarakat}

\subsection{Tahap Persiapan}

Kegiatan pelatihan ini dilaksanakan secara bertahap yang diawali dengan survei lokasi, penyusunan bahan atau materi pelatihan dan meminta kesediaan waktu para guru untuk mengikuti pelatihan. Selanjutnya, secara teknis pelaksanaan kegiatan ini berupa pelatihan penggunaan aplikasi Zoom untuk membantu proses pembelajaran daring kepada para guru SD Negeri 10 Cakranegara. Adapun beberapa peralatan yang diperlukan untuk menunjang kegiatan pelatihan ini adalah sebagai berikut:

1. Seperangkat komputer yang terhubung dengan internet.

2. LCD proyektor

3. Materi pelatihan

4. Snack sebagai perangsang kegiatan

\subsection{Tahap Pelaksanaan Pelatihan}

Pelatihan penggunaan aplikasi Zoom untuk membantu proses pembelajaran daring pada masa pandemi Covid19 ini dilaksanakan secara luring agar peserta dapat lebih mudah memahami materi serta para tutor dapat memantau secara langsung serta memberikan arahan jika peserta mengalami kesulitan. Materi yang akan disampaikan pada saat pelatihan akan dibagi menjadi 2 (dua) sub pokok pembahasan yakni yang pertama adalah penjelasan mengenai apa itu aplikasi Zoom serta apa saja fitur-fitur yang dapat dimanfaatnya untuk menunjang proses pembelajaran jarak jauh atau pembelajaran daring agar dapat lebih efektif dan efisien jika dibandingkan dengan proses pembejaran yang banyak digunakan saat pandemi Covid-19 ini yang dengan hanya memanfaatkan grup Whatsapp sebagai media untuk pemberian tugas kepada peserta didik tanpa adanya interaksi lebih lanjut. Pembahasan yang kedua yakni mengenai tata cara pengelolaan aplikasi Zoom yang meliputi tata cara pembuatan akun Zoom, pembuatan pertemuan daring (meeting online) saat akan memulai pembelajaran, tata cara mengundang peserta didik untuk bergabung dalam pertemuan daring, serta tata cara melakukan pembelajaran dan merekam proses pembelajaran yang kemudian hasil rekaman tersebut nantinya dapat diunggah ke platform Youtube dan dapat dibagikan ke peserta didik agar dapat ditonton kembali.

Beberapa metode pelatihan yang akan digunakan untuk melaksanakan kegiatan ini antara lain: 
1. Metode Ceramah

Metode ceramah digunakan untuk memberikan penjelasan mengenai apa itu aplikasi Zoom serta manfaatnya untuk membantu proses pembelajaran daring, serta memberikan motivasi kepada para guru agar mau memanfaatkannya.

2. Metode Tutorial

Metode tutorial digunakan agar peserta pelatihan dapat benar-benar memahami setiap langkah yang diberikan oleh tutor dengan cara peserta mengikuti setiap petunjuk yang diberikan oleh tutor.

3. Metode Praktik

Pada metode ini peserta pelatihan mempraktikkan setiap langkah kerja sesuai dengan materi pelatihan yang diberikan dan sesuai dengan arahan dari tutor.

4. Metode Tanya Jawab/Diskusi

Metode tanya jawab atau diskusi sangat penting bagi peserta pelatihan karena metode ini memberikan kesempatan pada peserta untuk menggali pengetahuan lebih jauh lagi mengenai aplikasi Zoom dan juga pengalaman setalah praktik penggunaannya.

\subsection{Tahap Evaluasi}

Evaluasi kegiatan pelatihan penggunaan aplikasi Zoom untuk membantu proses pembelajaran daring dilaksanakan pada saat pelaksanaan kegiatan dengan melihat partisipasi peserta dalam mengikuti pelatihan, pemahaman materi, serta pada saat peserta mempraktikkan proses penggunaan aplikasi Zoom. Di samping itu, komunikasi lanjutan dapat dilakukan melalui email, grup Whatsapp ataupun melalui Facebook untuk melakukan diskusi antara tutor dan peserta pelatihan tentang kendala-kendala yang dihadapi selama percobaan penggunaan aplikasi Zoom untuk membantu proses pembelajaran di Sekolah.

\section{Hasil dan Pembahasan}

Kegiatan pengabdian masyarakat kepada para guru SD Negeri 10 Cakranegara telah dilaksanakan dalam 1 (satu) hari yakni pada tanggal 28 Agustus 2020. Kegiatan pelatihan ini dilaksanakan secara luring (offline) dan bertempat di salah satu ruang kelas SD Negeri 10 Cakranegara. Jumlah peserta yang hadir mengikuti pelatihan adalah sebanyak 14 orang dari total 22 tenaga pendidik yang ada pada SD Negeri 10 Cakranegara. Pelatihan dibuka dengan sambutan oleh Kepala sekolah SD Negeri 10 Cakranegara seperti yang terlihat pada Gambar 1. Kemudian, pelatihan dimulai dengan sesi pertama yakni pemaparan tentang pengenalan aplikasi Zoom, serta fitur-fitur apa saja yang dapat digunakan untuk menunjang proses pembelajaran seperti yang terlihat pada Gambar 2.

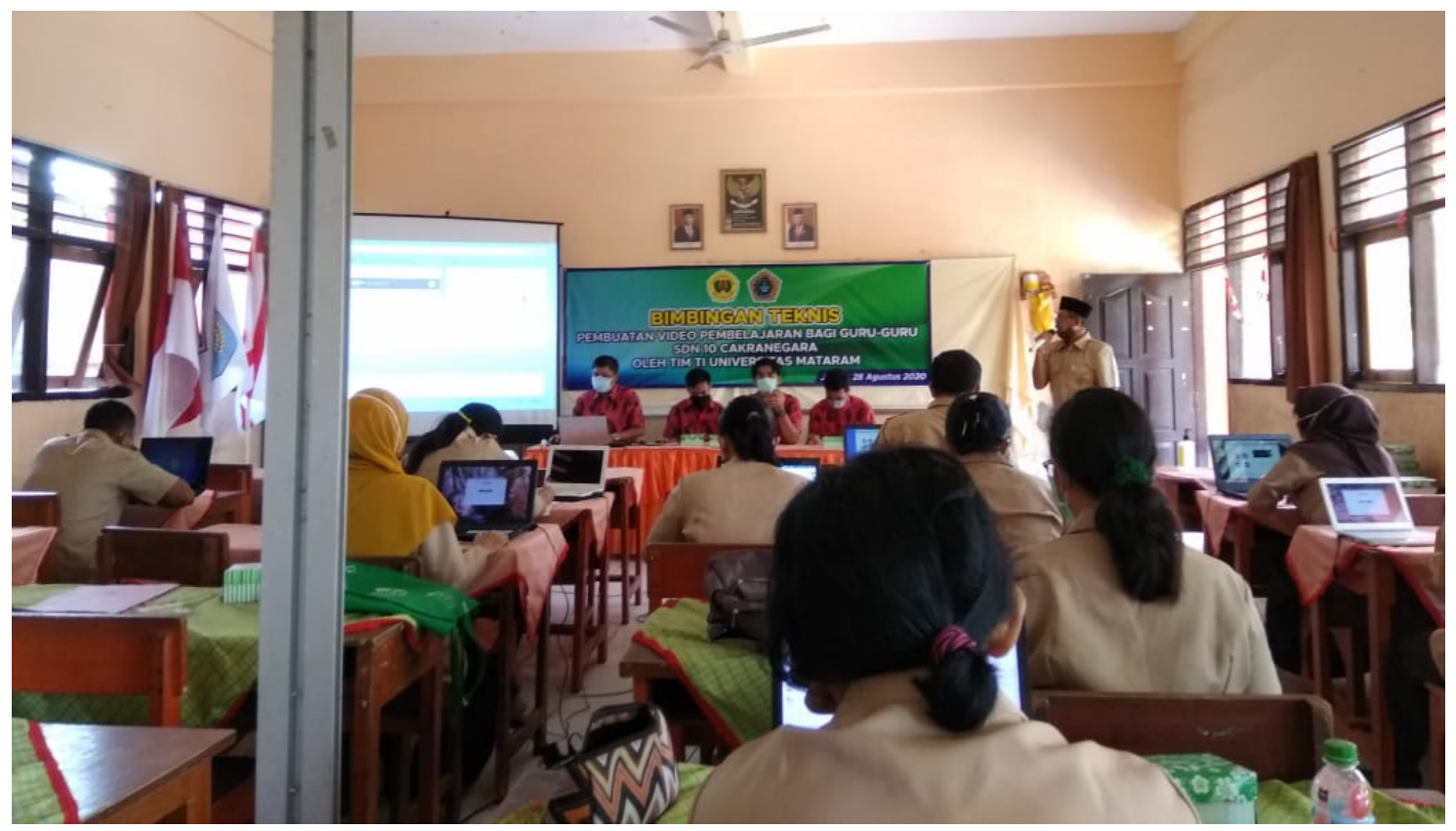

Gambar 1. Sambutan Kepala Sekolah SD Negeri 10 Cakranegara untuk membuka acara pelatihan 


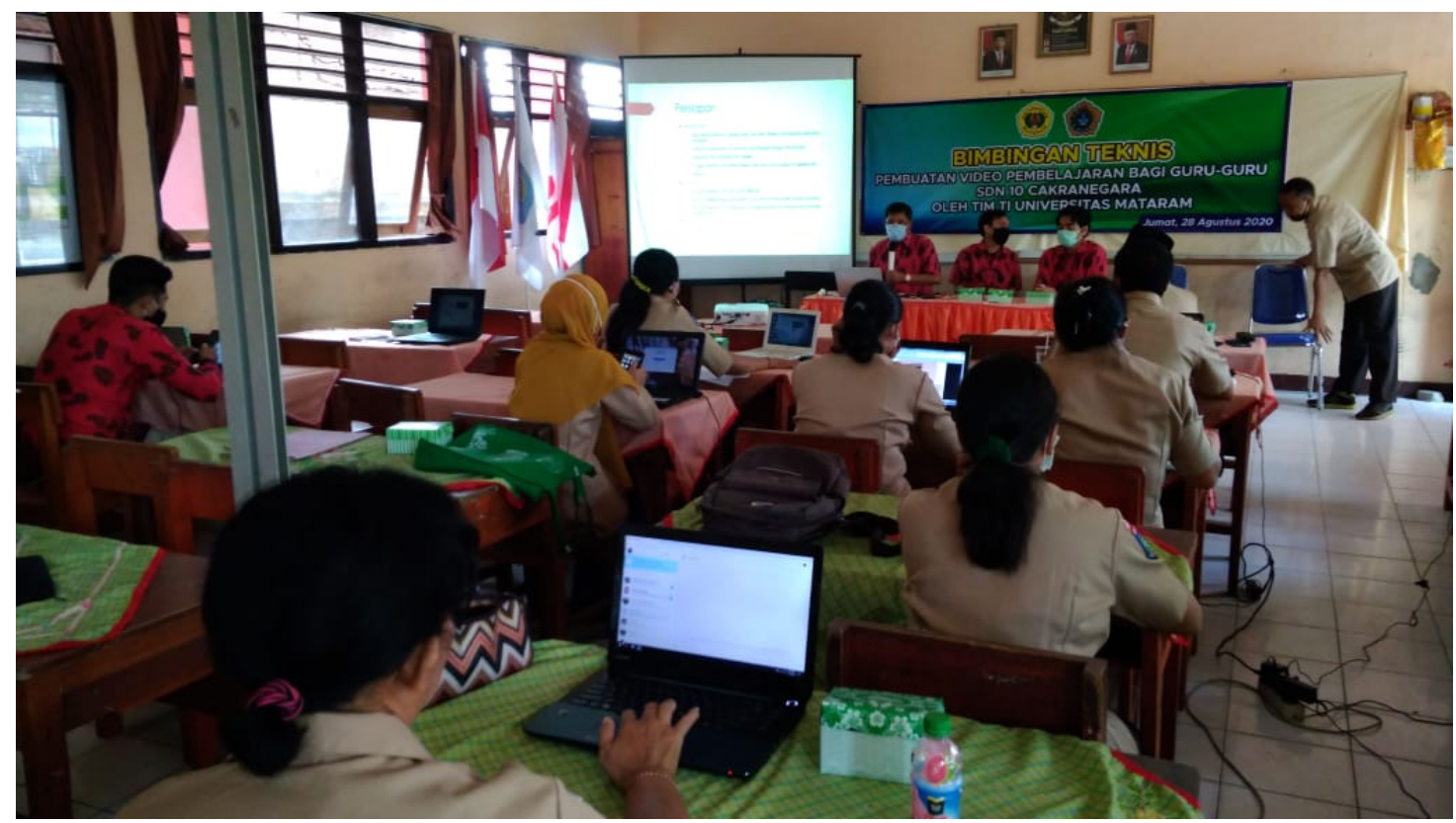

Gambar 2. Pemaparan materi penggunaan aplikasi Zoom untuk proses pembelajaran daring oleh Tutor

Setelah pemaparan materi pengenalan aplikasi Zoom, kegiatan pelatihan dilanjutkan dengan memberikan tutorial serta penjelasan mengenai pengelolaan aplikasi Zoom yang dimulai dengan mengajarkan langkah-langkah pembuatan akun Zoom pada laman web https://zoom.us. Setelah semua peserta berhasil membuat akun Zoom, pelatihan kemudian dilanjutkan dengan penjelasan langkah-langkah proses instalasi aplikasi Zoom baik pada laptop ataupun smartphone para peserta. Instalasi pada smartphone bertujuan untuk meberikan contoh bagaimana penggunaan aplikasi Zoom pada smartphone, hal ini dapat membantu para guru nantinya untuk membantu para peserta didik untuk mengikuti pembelajaran daring menggunakan smartphone apabila tidak memiliki perangkat komputer atau laptop di rumah masing-masing.

Pada sesi selanjutnaya, peserta pelatihan diberikan penjelasan mengenai tata cara penggunaan dan pengelolaan aplikasi Zoom untuk mengajar daring. Dalam tutorial penggunaan aplikasi Zoom untuk mengajar daring, dijelaskan bagaimana langkah-langkah untuk membuat pertemuan daring serta cara mengundang para siswa untuk bergabung dalam pertemuan daring tersebut. Untuk mengundang para siswa untuk bergabung ke dalam permbelajaran daring, peserta pelatihan diarahkan untuk memanfaatkan grup Whatsapp yang telah dibuat oleh para guru berserta para peserta didik. Dengan adanya grup Whatsapp tersebut sangat memudahkan untuk mengundang peserta didik karena para guru cukup untuk menyebarkan tautan untuk bergabung dalam grup tersebut dan kemudian peserta didik hanya cukup meng-klik tautan dan akan secara otomatis diarahkan menuju aplikasi Zoom yang telah terpasang pada smartphone ataupun laptop.

Selanjutnya, peserta dijelaskan cara untuk mengelola pertemuan daring, yakni dimulai dari bagaimana cara menampilkan slide materi presentasi yang akan digunakan sebagai materi ajar kepada peserta didik menggunakan aplikasi powerpoint ataupun media ajar digital lainnya. Materi presentasi ini berperan cukup penting dalam proses pembelajaran daring untuk memudahkan para peserta didik untuk dapat mengikuti pembelajaran dengan lebih baik. Kemudian peserta pelatihan juga diajarkan bagaimana cara mengontrol audio peserta didik agar tidak mengganggu pada saat pemaparan materi oleh guru.

Pada sesi terakhir, peserta diminta untuk mempraktikkan setiap langkah kerja penggunaan aplikasi Zoom untuk proses pembelajaran daring sesuai dengan materi pelatihan yang telah diberikan. Tutor dan peserta juga aktif melakukan diskusi terkait materi pelatihan yang masih belum jelas pada sesi terakhir pelatihan ini seperti yang terlihat pada Gambar 3 dan Gambar 4. Hasil dari praktik tersebut, peserta telah mampu menggunakan aplikasi Zoom untuk proses pembelajaran daring dengan baik. Pada sesi terakhir ini juga dicontohkan cara untuk melakukan unggah hasil rekaman pembelajaran ke kanal Youtube milik sekolah. Rekaman ini kemudian dapat dibagikan kembali kepada para peserta didik untuk dapat ditonton kembali jika ada kesulitan dalam pemahaman materi dikarenakan terjadi gangguan koneksi sehingga proses pembelajaran sempat terputus atau terganggu. 


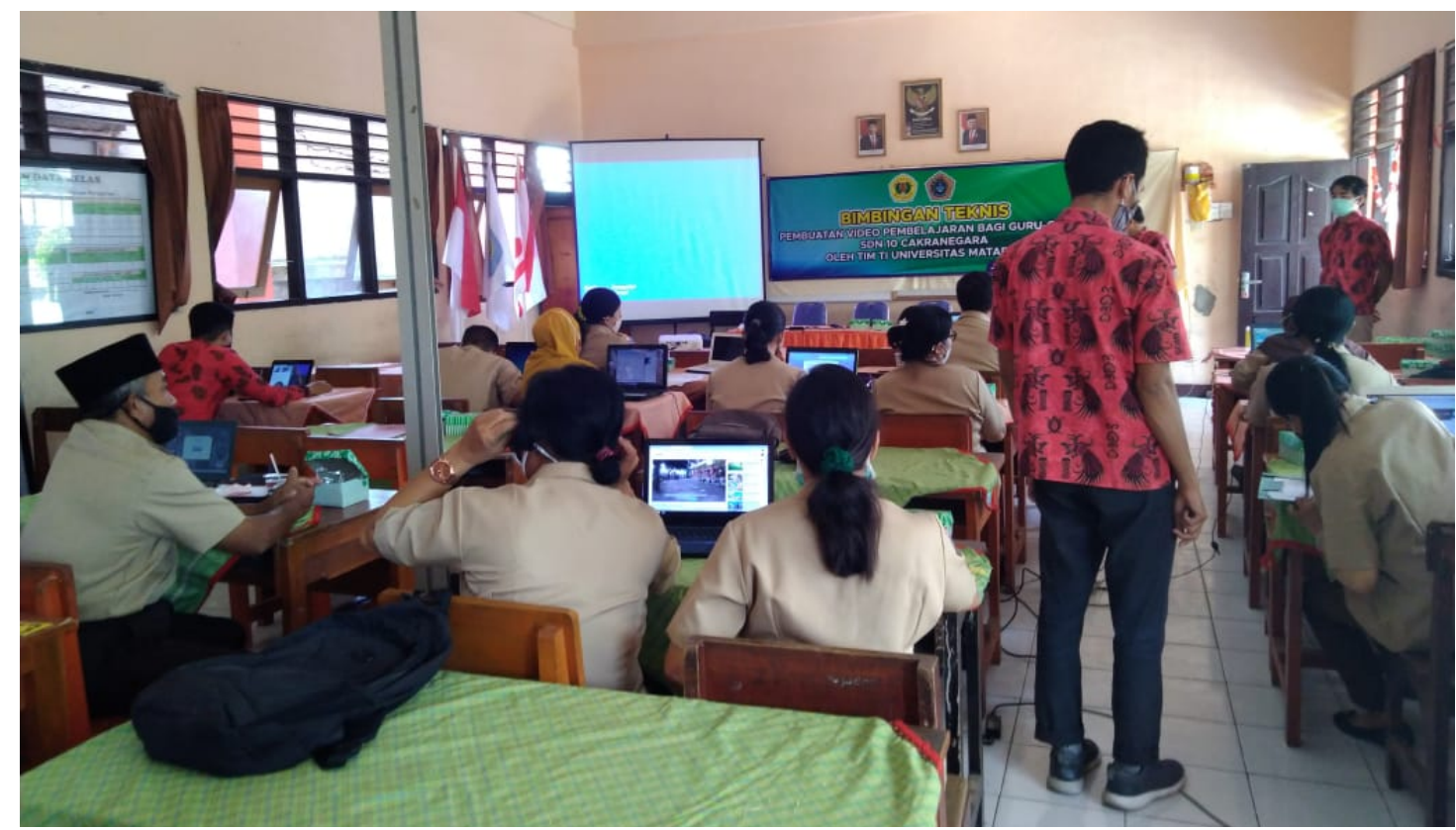

Gambar 3. Peserta pelatihan berdiskusi terkait materi dengan para tutor

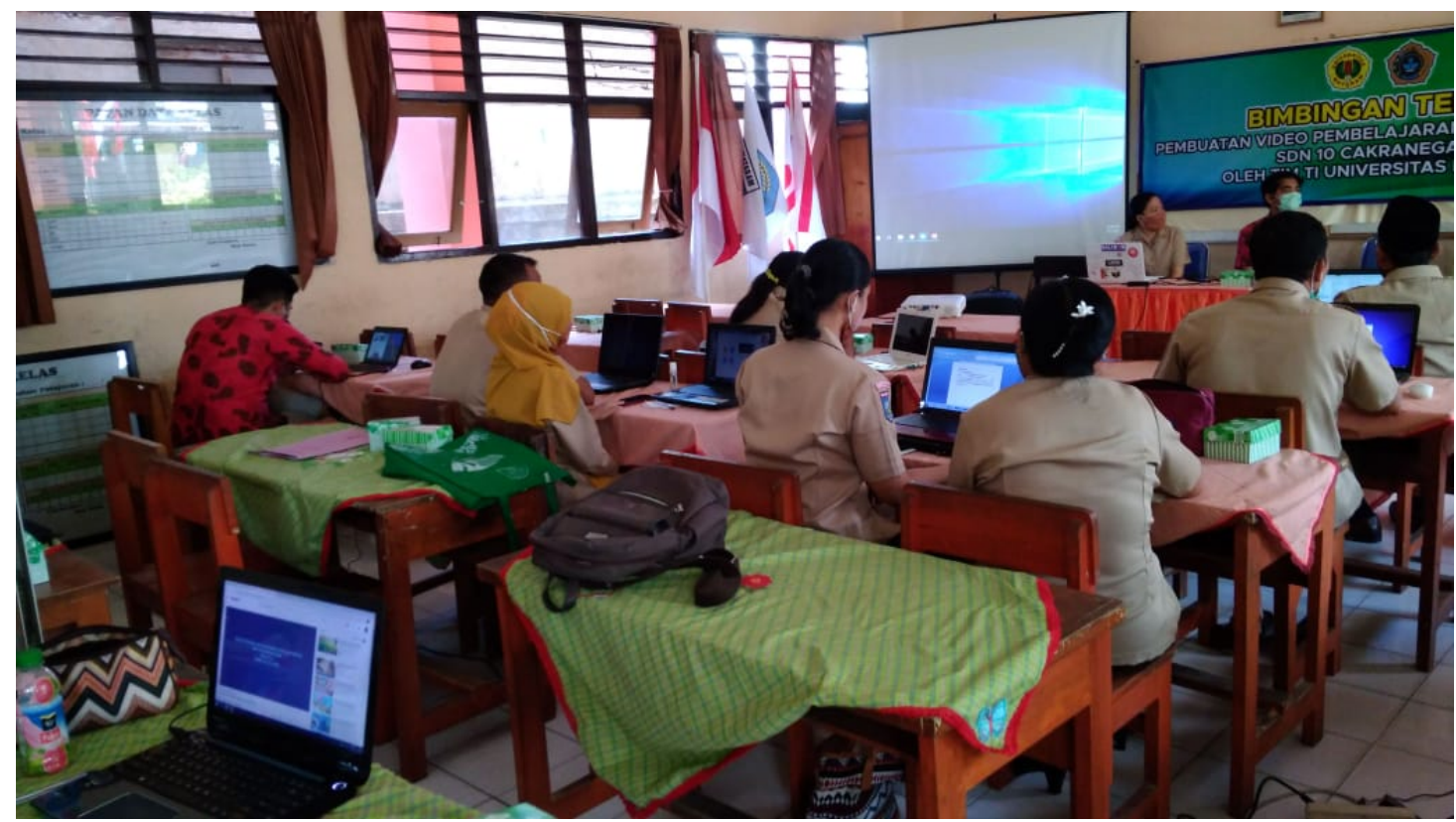

Gambar 4. Salah satu peserta pelatihan saat sedang mempraktikkan penggunaan aplikasi Zoom

Proses pembelajaran tatap muka secara daring menggunakan aplikasi Zoom ini memberikan manfaat yang cukup banyak ditengah kesulitan yang dialami dalam para guru, peserta didik serta para orang tua perserta didik akibat dari efek pandemi Covid-19 ini. Namun, proses pembelajaran daring menggunakan aplikasi Zoom ini membutuhkan kuota internet yang cukup banyak, sehingga para guru disarankan untuk tidak menggunakan model pembelajaran ini secara terus menerus karena dapat memberikan beban tambahan berupa pembelian kuota internet kepada peserta didik ataupun para guru sendiri jika tidak mendapatkan bantuan kuota dari pemerintah. Selain itu, dengan tidak menggunakan model pembelajaran ini secara terus menerus juga untuk mencegah kebosanan dan kelelahan peserta didik karena duduk terlalu lama di depan layar komputer, laptop ataupun smartphone yang digunakan dapat proses pembelajarang daring. Alternatif model pembelajaran lainnya yang dapat dilakukan dengan menggunakan aplikasi Zoom sebagai variasi dalam proses pembelajaran jarak jauh adalah dengan cara para guru dapat merekam secara mandiri penjelasan terkait materi ajar yang akan disampaikan kepada peserta didik, kemudian hasil rekaman tersebut dapat diberikan ke peserta didik untuk dipelajari secara mandiri. 


\subsection{Faktor Pendukung}

Beberapa faktor pendukung keberhasilan kegiatan pelatihan ini, antara lain:

1. Dukungan dari pihak Program Studi Teknik Informatika maupun Fakultas Teknik Universitas Mataram dalam hal penyediaan dana dan materi pendukung.

2. Kerja sama yang baik dengan Kepala Sekolah serta semua guru SD Negeri 10 Cakranegara sebagai peserta pelatihan.

3. Pihak sekolah menyediakan fasilitas berupa ruangan, perangkat komputer, akses jaringan internet dan mengundang para guru untuk mengikuti pelatihan.

4. Antusiasme dan partisipasi aktif peserta saat pelaksanaan pelatihan.

\subsection{Faktor Penghambat}

Dalam pelaksanaan kegiatan pelatihan penggunaan aplikasi Zoom ini tentu tidak luput dari keterbatasan, faktorfaktor yang menjadi penghambat atau kendala dalam pelaksaan pelatihan yakni terjadinya gangguan koneksi internet pada WIFI yang disediakan oleh pihak sekolah sehingga para peserta dan tutor kesulitan mengakses aplikasi Zoom karena koneksi internet yang terhenti. Oleh karena itu, pelatihan sempat terhenti beberapa saat dan dibutuhkan beberapa waktu untuk menghubungkan kembali para peserta dengan menggunakan koneksi internet dari perangkat lain berupa WIFI dari smartphone yang telah disediakan oleh tim pengabdian masyarakat.

\section{KESIMPULAN DAN SARAN}

Berdasarkan pembahasan bab sebelumnya, dapat disimpulkan bahwa kegiatan pengabdian kepada masyarakat berupa pelatihan penggunaan aplikasi Zoom untuk proses pembelajaran secara daring di SD Negeri 10 Cakranegara telah terlaksana dengan baik dan lancar. Peserta pelatihan yang berjumlah 14 orang guru antusias mempraktikkan serta aktif berdiskusi dengan tim pengabdian mengenai materi pelatihan. Pelatihan ini telah berhasil mencapai tujuannya yakni meningkatkan pemahaman dan keterampilan para guru SD Negeri 10 dalam mengelola pembelajaran jarak jauh memanfaatkan aplikasi Zoom. Kegiatan ini merupakan salah satu kepedulian terhadap aktivitas belajar siswa di tengah pandemi Covid-19.

Untuk memaksimalkan hasil kegiatan pengabdian kepada masyarakat terkait pelatihan aplikasi Zoom untuk proses pembelajaran ini, ke depannya perlu untuk melibatkan mitra sekolah yang lebih banyak agar kegiatan ini memiliki diseminasi yang semakin luas. Selain itu, komunikasi yang lebih aktif antara tim pengabdian dengan mitra sangat diperlukan baik saat sebelum dan sesudah kegiatan, agar faktor hambatan kegiatan dapat dihindari dan hasil kegiatan dapat dievaluasi secara intensif.

\section{UCAPAN TERIMA KASIH}

Kegiatan pengabdian kepada masyarakat ini didanai menggunakan dana DIPA BLU Universitas Mataram Tahun Anggaran 2020, dengan surat perjanjian nomor 2007/UN18/LPPM/2020. Oleh karena itu, tim pengabdian kepada masyarakat mengucapkan terima kasih kepada Lembaga Penelitian dan Pengabdian Kepada Masyarakat (LPPM) Universitas Mataram yang telah memberi kesempatan dan bantuan dana kepada kami untuk melaksanakan kegiatan ini. Ucapan terima kasih juga kami sampaikan kepada Kepala Sekolah serta para Guru SD Negeri 10 Cakranegara yang telah menyiapkan sarana dan prasarana untuk terselenggaranya kegiatan pengabdian ini.

\section{DAFTAR PUSTAKa}

[1] Direktorat Promosi Kesehatan dan Pemberdayaan Masyarakat Kementrian Kesehatan Indonesia, "Informasi Tentang Virus Corona (Covid-19),” 2020. [Online]. Available: https://promkes.kemkes.go.id/informasi-tentangvirus-corona-novel-coronavirus. [Accessed: 02-Nov-2020].

[2] G. L. Widyaningrum, "WHO Tetapkan Covid-19 sebagai Pandemi Global, Apa Maksudnya?," 2020. [Online]. Available: https://nationalgeographic.grid.id/read/132059249/who-tetapkan-covid-19-sebagai-pandemi-globalapa-maksudnya. [Accessed: 02-Nov-2020].

[3] Kementerian Pendidikan dan Kebudayan RI, "Surat Edaran Nomor 4 Tahun 2020 Tentang Pelaksanaan Kebijakan Pendidikan dalam Masa Darurat Penyebaran Coronavirus Disease (Covid-19), Kementerian Pendidikan dan Kebudayaan Republik Indonesia." 2020.

[4] T. Belawati, Pembelajaran Online, no. December 2019. 2019.

[5] CloudHost, "Mengenal Aplikasi Zoom: Cara Install dan Fitur-Fitur Zoom Meeting [Lengkap]," 2020. [Online]. Available: https://idcloudhost.com/mengenal-aplikasi-zoom-cara-install-dan-fitur-fitur-zoom-meeting-lengkap/. [Accessed: 07-Sep-2020]. 
[6] Republik Indonesia, "Undang-Undang Republik Indonesia Nomor 12 Tahun 2012 Tentang Pendidikan Tinggi." 2012.

[7] Zoom.us, "Zoom Video Conferencing Plans \& Pricing.” [Online]. Available: https://zoom.us/pricing.

[8] Suhery, T. Putra, and Jasmalinda, "Jurnal Inovasi Penelitian," J. Inov. Penelit., vol. 1, no. 3, pp. 1-4, 2020.

[9] M. Muhammad Ihsan, Indri Anugrah Ramadhani, "Pelatihan Penggunaan E-Learning Menggunakan Zoom Cloud Meeting untuk Guru di SMK Muhammadiyah Kab. Sorong," J. ABDIMASA Pengabdi. Masy., vol. 2, no. 2, pp. 4953, 2019, doi: 10.2207/jjws.88.427.

[10] F. Ariadhy, Shulby Yozar., Nurohman, Sabar., Arkum, Darol., Handini, Widya., "Permasalahan Pembelajaran Jarak Jauh Di Era Pandemi," Pus. Penelit. Badan Keahlian DPR R, pp. 13-18, 2020. 